\title{
The Competence of Naming in the Second Language Acquisition of the Preschool-Aged Children
}

\author{
Rahayu Pujiastuti* \\ Faculty of Teacher Training and \\ Education \\ University of PGRI Adi Buana \\ Surabaya \\ Surabaya, Indonesia \\ rahayu_pujiastuti@unipasby.ac.id
}

\author{
Luluk Isani Kulup \\ Faculty of Teacher Training and \\ Education \\ University of PGRI Adi Buana \\ Surabaya \\ Surabaya, Indonesia \\ luluk@unipasby.ac.id
}

\author{
Dyah Rochmawati \\ Faculty of Teacher Training and \\ Education \\ University of PGRI Adi Buana \\ Surabaya \\ Surabaya, Indonesia \\ dyahrochma@unipasby.ac.i
}

\begin{abstract}
This study aims to describe: (1) how the preschool children's naming competencies in language acquisition, (2) how the naming competencies in language acquisition of preschool children relate to their cognitive development. It is a qualitative research The data source of this research is ten kindergartners who used Indonesian as a second language. Data collection was carried out crosssectionally through observation, fishing, recording, and field recording techniques. Data analysis was carried out through four steps, namely reducing and coding, presenting, interpreting, and concluding data. There are two results of this study. First, the competencies of naming preschool-age children in their second language acquisition included shortening, imitation of sounds, characteristics, materials, similarity, and new naming. Naming for something real is more mastered than abstract. Naming competencies in the surrounding people, animals, plants, and events are better than naming competencies for actions/ actions, nature/conditions, personal pronouns, and adverbs. Second, the preschoolers' competencies of naming in the acquisition of the second language was related to cognitive development. The proof, naming for something real is easier to master than abstract. Also, when giving a name to something, the preschoolers still experienced over-extension and under-extension. The accuracy of naming depended on the accuracy to provide semantic features. To be able to give semantic features properly, the children needed to understand well the extensions and intentions of something that must be named. This was influenced by the children's cognitive development.
\end{abstract}

Keywords - Competence, Naming, Second Language Acquisition

\section{INTRODUCTION}

In language acquisition, there are two important things, namely competence and performance. Competence refers to language knowledge or basic knowledge about a fact, event, and language system (Brown, 2007). Competence in language acquisition includes four language components, namely phonological, morphological, syntactic, and semantic (Carrol, 2001; Fromkin, Rodman, and Hyams, 2011). Competence is an ability that cannot be observed because it is internal so that its realization is done with performance. Competence and competency are interchangeable. Though competence is more often used to describe a person's general ability, while competency is more often used to describe a person's ability to perform a certain task. Performance is the use of language in real situations or concrete forms of language use or language behavior. The performance consists of two processes, namely understanding and producing language (Harley, 2008).

Semantic competence is one of the competencies needed by children when communicating. With semantic competencies, children can understand and convey the purpose or content of the message. Researching on this, as what this study did, would greatly benefit professionals who are responsible for the children's learning and development. Since this course of time constitutes "the golden age", the study would bring about the positive impacts on the children's future.

In semantic competence, there is a naming competency. That is, the knowledge possessed when giving names. So far there have been researches related to semantic competencies of preschoolers that has been directed at under-extension and over-extension (Halid, 2015), the denotative meaning reviewed lexically (Nurjamiaty, 2015), and semantic function of speech (Martubongs, 2016), and many more. However, there has not much research on naming. Even though there were researches on semantic representation and naming as done by Gregor, Newman, Reilly, and Capone (2002) they compared the naming of children with hearing impairment and children in general. This research, however, investigated the competency of naming preschoolers, which is also important because it can reveal the characteristics of naming competencies to be used in learning in the kindergarten level.

Naming is the labeling or word for an object, situation, and event (Palmer; 1983; Steinberg, 2001). Naming is carried out by children who learn language by speaking the sounds of language by an object, both objects, situations, events, actions, traits, and functions that are around it (Fernald and Marchman, 2006).

There are several reviews about naming. Based on denotative meaning, naming can be related to word types, such as nouns, verbs, adjectives, and so on. Based on the background of the child to give a name, naming occurs because of imitation of sound, mention of parts, characteristics, inventors and makers, place of origin, material, similarity, shortening, and new naming (Chaer, 2009).

In order for the research direction to be precise, prior to the study, the initial observations were made on three 
preschool age children who used Indonesian as a second language. The following information is obtained.

\author{
Rt : Ris, ini buyaya? (while pointing at the picture) \\ Rrs : Ndak, tekek tapi besar \\ $\mathrm{Gr}$ : Bukan ini komodo \\ Abd : Bodoh ya, Bu? \\ Gr : Ndak boleh gitu!
}

When examined, the performance in the illustration provides important information. First, naming with shortening occurs when Rt calls Rrs by shortening from its name, namely Ris. The naming of shortening by Rt by stating the syllable of the full name can give a psychological picture.

Second, naming due to similarity occurs when Rt and Rrs give the name of the komodo (komodo dragon) with buyaya (crocodiles), and tokek (geckos). That is because physically the three are almost the same. The physical similarity possessed by the three reptiles caused the two children to place known semantic features of animals, namely buyaya (crocodiles) and takek (geckos) on animals known as new komodo (komodo dragon)

Third, the inaccuracy in naming adjectives occurred when Abdul said his friend was stupid because he did not understand the intention of the word. Thus, children do not yet have the naming competence are associated with the meaning of the denotation of the type of adjectives.

The three data in the illustration provide important research information on naming competencies. Naming competencies with shortening, naming with physical characteristics, and inaccurate naming characteristics can provide information about the characteristics of preschoolers' naming competencies in acquiring a second language in the form of Indonesian. It could provide information about the cognitive development of children. This is consistent with the statement of Brown (2007) and Steinberg (2001) that cognitive capacity determines the linguistic structure and process that underlies the understanding and production of speech. The children's cognitive development lays foundation of their language development. By knowing the characteristics of the children's naming competencies and cognitive development, teachers and parents can provide appropriate attitudes so that they are useful to help the development of children's naming competencies.

Based on these explanations, this paper discusses (1) naming competencies in language acquisition for preschoolers, (2) the relationship between naming competencies in language acquisition for preschool children and their cognitive development. According to Affendras (1980) and Ellis (1985), the term language acquisition is used in this study because when acquiring language, children also learn the language. Acquisition refers to the conscious or subconscious process of acquiring language.

\section{RESEARCH METHOD}

This research is qualitative research using cross-sectional data collection methods. 'The form of data was the preschoolers' utterances when naming that could reveal their competence of naming in the acquisition of Indonesian as their second language. The subjects of the study were ten students of Group A in Belia kindergarten because only ten students in the kindergarten were those who used Indonesian as a second language. The number taken was in accordance with the opinion of Ingram (1992) regarding language acquisition that the absolute minimum number of data sources is three people.

There are several data collection techniques used, namely observation, fishing, field recording, and recording. The data collection instruments included visual media, audiovisual media, and realia, for instance, images, recordings, real objects (flowers, toys, cakes, etc.). The data collection took the following stages: (1) determining patterns for collecting data; (2) making observations, both participatory and nonparticipatory, (3) transcribing oral data produced by children, (4) triangulating data.

Analyzing the data is done by sorting, turning and connecting techniques (Sudaryanto, 1992). Data analyzing instruments in the form of tables are useful for (1) reducing data to be able to see units of data, (2) presenting data so that it can reflect the data as a whole, both data of every aspect and relationship between aspects are visible making it easier to interpret and make conclusion The procedure used, namely reducing, presenting, interpreting, and summarizing data. The procedure was applied using the data analysis techniques and instruments.

\section{RESULTS AND DISCUSSION}

\section{A. Naming Competencies}

The form of competencies in naming possessed by the preschool-aged children in the acquisition of a second language in the form of Indonesian, including shortening, imitation of sounds, characteristics, materials, similarity, and new naming.

1) Shortening: In this study, shortening occurs because the subjects do the naming by mentioning a part of the word or sentence in question. The shortening of the subject can be one syllable or two syllables. The following are examples of naming data with a shortening of the subjects in this study.

$$
\begin{array}{ll}
\mathrm{Pmd} .1 & \\
\mathrm{Gr} & : \text { Temannya diberi! } \\
\mathrm{Nn} & : \text { [dikit] } \\
\mathrm{Gr} & \text { : Sedikit....Ndak boleh pelit } \\
\mathrm{Nn} & : \text { [dikit] }
\end{array}
$$

Pmd.2

Ang : [ni ñakku]

$\mathrm{Gr}$ : Ini punyaku

Ang : [nda?/ ñakku]

Pmd.3

Pn : Siapa yang nggambar?

$\mathrm{Nr}$ : [Lis]

Pn : Lilis

$\mathrm{Gr}$ : [Lis]

In the first data, the children call an indefinite number by shortening. The word is sedikit shortened into two syllables [dikit]. The same thing also appears in the second data when the child shortens his friend's name Lilies which should be shortened to [Lis]. The third data shortening that occurs in 
this sentence Ini kepunyaanku. Both words in the sentence are pronounced [ni ñakku].

Some other subjects also do the naming with shortening when stating greetings or names of friends, such as tante (aunt) becomes [tə], pipis (piss) becomes [pis], Bramastya becomes [Bam], and Mbah Putri (grandmother) becomes [uti], bunda (mother) becomes [bun] or [nda]

Shortening of the subject by calling words or sentences into one syllable or two syllables provides important information because Indonesian children generally digest vocabulary through the decapitation process. The input received by the children is certainly not possible directly intact form. To be able to produce the word sepeda cannot be done directly, but must be assisted by the syllables. The beheading does not mean that it does not describe anything. That is because beheading requires psychological processes and concerns the cognitive abilities of children (Dardjowidjoyo, 2000).

2) Imitation: Naming with imitation of sound is also done by the subjects although not too much. Naming with sound imitation is used by children to name animals. In addition to naming cecak (lizard) dan təkek (geckos) some animals have common names, but the subject names according to the sound. The following are examples of naming data from sound imitation produced by the subjects.

$\mathrm{Pb} .1$

Ang : [gukguk]

Gr : Anjing

Ang : [anjIn]

After a long conversation, the teacher asked again

Pn : Apa?

Ang : [gukguk]

$\mathrm{Pb} .2$

And : Tikus. Takut

Rnl : [cicit]

And : Kok cicit sih. Tikus ya?

Ang : Di rumahku ya ada cicit itu, tapi namanya titus.

Gr : Tikus. Cicit itu bunyinya

$\mathrm{Pb} .3$

B1 : Ini pus?

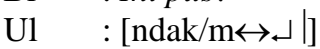

Gr : Pus sama meong sama

$\mathrm{Pb} .4$

Ulf $\quad:[\therefore \mathrm{mbi} ? \mathrm{ma} \therefore \mathrm{m}]$

Pn : Kambing

Ulf : (Hanya melihat peneliti)

Pn : Kambing ya?

Ulf $\quad:[\therefore$ mbi? aja $]$

In all four data, the child names animals with sound imitations. Animals that are already known by the public by name anjing (dog), tikus (mouse), kucing (cat), and kambing (goat), given a name by the child by using a basic sound imitation so that the names of the animals produced are stated with [gukguk], [cicit], $[\mathrm{m} \leftrightarrow\lrcorner \mid]$, and $[\therefore \mathrm{mbi}$ ?]. Knowledge of the sound that is heard makes children determine the sound like one of the semantic features of something that emits sound. Giving a name to the sound because it is considered very unique.
Naming with the imitation of the sound can be an underextension event because the child considers it something that only belongs to an object. For example, when a child names

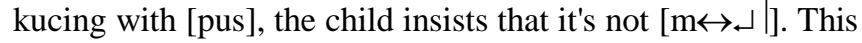
happens because the children interpret a meaning only refers to one specific thing. The children assume that pus is only an animal in the house, whereas what is found at school is meong because of its sound.

3) Sifat Khas: Naming a characteristic means giving a name that is done by mentioning the characteristics, characteristics, or characteristics of an object, person, object, situation, or event. Naming data related to these characteristics are not many because there are only two data. The emergence of naming with these special characteristics because the two subjects who are quarreling so that both mock each other and give each other a name with a characteristic or characteristic second, namely gendut (fat) and keriting. (curly). The following excerpts from the two data.

Sk.1

Ic : [bu/gəndut nakal]

Gr : Ndak boleh gitu. Panggil namanya!

Ic : (Hanya melihat guru)

$\mathrm{Gr}$ : Andre

Ang : [gəndut]

Sk.2

And : [krItIl]

Gr : Ayo, manggil yang baik. Angga.

And : [ $[\mathrm{krItI} \mid]$

$\mathrm{Gr} \quad$ : Gak boleh marah

And : (Menunduk)

Naming competence is based on the specific characteristics displayed by the subjects and tends to be physical. This is seen in two quotations. Adjectives word gendut (fat) and keriting (curly) are visible physically making it easier for the subject to give semantic features to the two words.

In semantics, naming with these characteristics causes the transposition of meaning. When naming these special traits, the subject changes adjectives into nouns. Gendut (fat) and keriting (curly) words are types of adjectives used to name someone so that adjectives become nouns. sound.

4) Material: Naming based on material, occurs on objects known in the child's daily life. The following data contains naming based on ingredients.

Bhn.1

And : Lho, ini lho tak pakai bajuku

Rnl : [ka $\triangleleft \mathrm{s}]$

$\mathrm{Gr} \quad$ :Ini baju, tapi dari kaos. Itu baju dari kain

Rnl : $[\mathrm{ka} \triangleleft \mathrm{s}]$

Bhn.2

Pn : Apa itu? (Pointing cat fur)

Ang : [rambUt]

Pn : Bulu. Tirukan!

Ang : [bulu]

Bhn.3

Pn : Makan apa? 


$\begin{array}{ll}\text { Bl } & \text { : [c } \downarrow \text { kat }] \\ \text { Ml } & \text { : Kata mamaku, ini waper } \\ \text { Bl } & \text { : [c } ₫ \text { kat }]\end{array}$

In all three data, children appear to give the name of something based on the same material, element, or component as they know it. The children do not give names based on the name that is generally known, namely baju (clothes), but on kaos (T-shirts). Even though it has been explained by the teacher, the child still states that only sports clothes are called kaos (T-shirts). In data 2, the children named their bulu (fur) by rambut (hair) because of the similarity of ingredients, although bulu (fur) tends to be shorter than rambut (hair). In data 3 , the child sees coklat (the chocolate) element or ingredient in wafer (the wafer) that is being eaten so that it names coklat (the chocolate)

Naming using the basic material as shown in the conversation quotation turns out to be in terms of the naming competencies that the child does not have well, causing under-extension and over-extension. In the first data, there is an under-extension or narrowing of meaning because the child assumes that only sports clothes are called kaos. In the second and third data, there is an over-extension or expansion of meaning because the child places the semantic features rambut (hair) dan coklat (chocolate) on bulu (fur) dan wafer (wafer)

In semantic acquisitions, it often happens underextension, namely the narrowing of meaning and overextension, namely the expansion of meaning or excessive lengthening. This relates to the child's semantic competence which is still limited so that the child applies one entity's features to another. Both under-extension and over-extension are determined by the child's understanding of the object's semantic features named, whether in the form of shape, texture, size, or motion (Nurjamiaty, 2015).

5) Similarity: In semantic theory, the similarity is usually used for something metaphorical because it tries to equate and compare the meaning of a word with the lexical meaning of another word. For example, the word kepala means 'upper body'. By using this basis, the words kepala sekolah (of the principal or head master), kepala surat (head of the letter), kepala meja (head of the desk) and so forth emerged. These words have the same semantic feature, which is 'the upper part which is very important in the body.

In this study, the words show slight differences, but in principle they are same because it also refers to the same semantic features in a word compared to other words. The similarity in this study is namely the use of the name of something known for something new known because it has the same extension also the same semantic features.

Based on the results of the study, there are several naming done by the subjects due to similarities, namely in animals, fruits, and limbs. The following similarity data were obtained from this study.

KSr.1

$\mathrm{Nn} \quad$ : [ayam] (While pointing at the picture of a bird)

Pn : Ini burung

$\mathrm{Nn}$ : [burUn].

The similarity of ayam (chickens) and burung (birds) is due to the competency of naming children to see the similarity of semantic features in the same two objects from physical form. Children who have understood the features of ayam [chickens], namely [+ winged], [+ beaked], [+ twolegged], [+ flying] use these features for burung (bird)..

Other similarities appear in cecak (lizards) and kadal (lizards). The subject stated kadal (lizards) with cecak (lizards)

KSr.2

During break time, Bl enters the classroom and informs the teacher by pointing out. Teachers and researchers come out and see something in the bush; something that B1.

$\begin{array}{ll}\text { Pn } & : \text { Apa? } \\ \text { B1 } & :[\mathrm{t} \therefore \mathrm{k} \varepsilon \mathrm{k}] \\ \mathrm{Pn} & : \text { Kadal } \\ \mathrm{Bl} & :[\mathrm{t} \therefore \mathrm{kek}]\end{array}$

In the quote, or birds, it appears that the subject gave the name of kadal (lizard) dengan $t .: k e k$ (gecko). The subject uses $t .: k e k$ semantic features for the word kadal that has physical similarities, namely [+ animal], [+ reptile $],[+$ length], and [+ quadruped].

In addition to these data, the subjects also gave names to other objects due to similarities, including sapi (cows) with kambing (goats), buaya (crocodiles) with komodo (komodo dragons), and hidung (nose) with belalai (proboscis).

The name was given because of the similarity in physical form. Naming the physical likeness will disappear if the subjects have understood every semantic feature of each object. The similarity understood by the subjects is related to something concrete.

Naming with similarity not only appears for noun objects but also adjectives, namely words sombong (arrogant) and nyala (flame).

KSr.3

When subjects are playing soccer, the ball is rolling away from the playground. One subject asked his friend to take it, but his friend did not want it so the subject chased his friend

And $\quad:[\mathrm{s}\lrcorner \mathrm{mb}\lrcorner \mathrm{y} \ldots \mathrm{s}\lrcorner \mathrm{mb}\lrcorner \mathrm{y}]$

Bl : (Mengejek sambil menjulukan lidahnya)

KSr.4

At that time $\mathrm{Kv}, \mathrm{Pn}$, and $\mathrm{Gr}$ in the yard, suddenly the cloudy atmosphere turned hot
$\mathrm{Kv} \quad$ : [Lho....ñala] (While looking at the sky)
Pn : Bukan. Panas
Gr : Panas
Kv : (Hanya melihat guru)

Both naming is done on certain characteristics and circumstances. The words sombong and nyala are not yet understood by the research subjects. This is understandable because adjectives or state words are abstract so it is difficult for the subject. The word sombong (arrogant) is equated with pelit (stingy). Both refer to qualities that are displeased or displeasing others. The word sombong (arrogant) means unfriendly or like "exalting heart", while the word pelit (stingy) means not giving to others, including giving help. This is what makes the inaccuracy of naming sombong 
In the second data it is stated that there is a word nyala for the situation from dim to bright; likened panas. Both refer to the same state from dark to light

6) New Naming: New naming is usually used to replace old names that are considered inappropriate, impolite, less subtle, or not by existing norms in the community, For example, the word tunawisma (homeless) replaces the word gelandangan (homeless), pramuniaga (saleswoman) replaces pelayan toko (shopkeepers).

In this research, there is a new naming produced by research subjects. Here is an example,

PB.1

Ang : (Shouting because he knows there are caterpillars) [Ada jabay bayik]

Pn : Apa?

Ang : [jaban bayik]

Pn : Itu ulat

PB.2

Rnl : [Ini ontet sapa?]

And : Apa?

Gr : Apa?

Rnl : [əntet]

And : Kok entet?

In both conversations, it appears that the research subjects produce new names for ulat (caterpillars) to be [jabay bayik] and the word train to [əntet]. What happened in the first data is surprising because [jaban bayik] is known in Javanese culture. The naming is usually used by parents to ask God to be kept away from disasters or bad things because they will do or know something. In the second data, the naming arises because the subject gives its name based on how the toy in the form of a train is operated by pressing the button. The concept of 'squeeze' is what is used as a name.

\section{B. Relationship of Naming Competencies with Cognitive Development}

Language acquisition, concrete including second languages, uses the basis of children's cognitive development. As explained, competence is one of the things gained in language acquisition. In language acquisition, there is a sequence of acquisition which is called language development.

Children's language development refers to the interaction of children's perceptions with their cognitive development which is influenced by the child's environment, both linguistically and non-linguistically. Thus, cognitive capacity determines the linguistic structure and processes that underlie speech understanding and production. With the cognitive processes that occur in the brain, every child can manage and understand the events that exist in their environment. Therefore, continuous cognitive development will generally be followed by linguistic development or reflected in the child's language (Brown, 2007; Fernald and Marchman, 2006; Slobin, 1991). When related to naming competencies explained that the development of naming competencies also uses the basis of cognitive development

According to Moskowitz, at first, children used a specific name for a particular object. However, due to a lack of understanding of the name of an object, known names are used on newly recognized objects. Over time and cognitive development of children, the correct naming for an object will be obtained When related to naming competencies explained that the development of naming competencies also uses the basis of cognitive development. This result is consistent with the one of Chierchia et.al. (2004) revealing that the children did not lack any kind of semantic competence and in particular know which word is more appropriate to the context. It is similar to 10 children in the process of development of language, between three and four years old age without complaint and/or hearing and cognitive impairments as studied by Silva et.al (2013).

The result also shows that there is a new naming produced by the research subjects. This supports what Moskowitz in Dardjowidjoyo (2000) suggests that, at first, children used a specific name for a particular object. However, due to a lack of understanding of the name of an object, known names are used on newly recognized objects. Over time and cognitive development of children, the correct naming for an object will be obtained.

Larson argues that a word is a combination of semantic features. In other words, meaning can be explained based on so-called semantic features or markers. Without semantic features, children cannot give names correctly. What might happen is over-extension and under-extension. Further, the study by Silva et.al. (2013) revealing that there was a higher occurrence of super-extension.

\section{CONCLUSION}

The results of this study provide two important pieces of information. First, the competencies of naming of the preschool-age children in the acquisition of Indonesian as a second language in the form of Indonesian, including shortening, imitation of sounds, characteristics, materials, similarity, and new naming. Naming for something concrete is more mastered than abstract. Naming competencies in people, animals, plants, and events that are around or have been seen are better than naming competencies for actions/actions, nature/conditions, personal pronouns, and adverbs. Second, the competency of naming preschoolers in the acquisition of the second language in the form of Indonesian is related to cognitive development. The proof, naming for something concrete is easier to master than abstract. Also, when giving a name to something, preschoolers still experience over-extension and underextension. The accuracy of naming depends on the accuracy to provide semantic features. To be able to give semantic features properly, children need to understand well the extensions and intentions of something that must be named. This is influenced by the cognitive development of children.

\section{ACKNOWLEDGMENT}

Thank you to PGRI Adi Buana University of Surabaya for providing support so that this research will be carried out. 


\section{REFERENCES}

Afendras, A. (1980). Patterns of Bilingualism. Singapore: Singapore University Press,

Brown, H. D. (2007). Principles of Language Learning and Teaching, New York: Pearson Education,

Carrol, S. E., (2001). Input and Evidence: The Raw Material of Second Language Acquisition. Philadelphia: John Benjamins Publishing Company.

Chaer, A. (2009). Pengantar Semantik Bahasa Indonesia. Jakarta: Rineka Cipta.

Chierchia, G., Guasti, M. T., Gualmini, A., Meroni, G., Crain, S., and Foppolo, F. (2004). "Semantic and Pragmatic Competence in Children's and Adults' Comprehension of Or" in Experimental Pragmatics. Ira A. Noveck and Dan Sperber. 283-301. New York: Palgrave Macmillan.

Dardjowidjojo, S. (2000). Echa: Kisah Pemerolehan Bahasa Anak Indonesia. Jakarta: PT Gramedia Widiasarana Indonesia.

Ellis, R. (1985) Understanding Second Language Acquisition. Oxford: Oxford University Press.

Fernald, A., and Marchman, V. A. (2006). "Language learning" in Handbook of Psycholinguistics, USA: Elsevier Inc.

Fromkin, V., Rodman, R., dan Hyams, N. (2011). An Introduction to Language. Canada: Wadsworth Cengage Learning.

Halid, E. (2019). "Analisis Pemerolehan Semantik Anak Usia 5 Tahun: Tinjauan Psikolinguistik", Jurnal Inovasi Pendidikan, vol. 6, no. 1. p 7-15, Maret 2019.
Harley, T. A. (2008). Psychology of Language. Canada: Psychology Press. Ingram, D. (1992). First Language Acquisition: Method, Description, and Explanation. Cambridge: Cambridge University Press.

Martubongs, A. (2016). "Peran Semantis Verba Bahasa Abun", Jurnal Kandai, vol. 12. no. 1. p 17-37, Mei 2016.

Mc. Gregor, K. K., Newman, R, M., Reilly, R. M. \& Capone, N. C. (2002). "Semantic Representation And Naming in Children With Specific Language Impairment". Journal of Speech, Language, and Hearing Research, 45(5), 998-1014, 2002

Nurjamiaty. (2015). "Pemerolehan Bahasa Anak Usia Tiga Tahun Berdasarkan Tontonan Kesukaannya Ditinjau dari Konstruksi Semantik", Jurnal Edukasi Kultura, vol. 2. no. 2. p 42-62, September 2015.

Palmer, F.R. (1983). Semantics. London: Cambridge University Press.

Silva, T. R. and de Oliveira e Britto, D. B. (2013). "Semantic changes in the statements of children in the process of development of oral language: preliminary study”.Rev.CEFAC, vol.15, no.6. São Paulo Nov. December 2013.

Slobin, D. I. (1991). Psycholinguistics, (Ton Ibrahim, Penerjemah), Glenview, Illinois: Scott, Foresman, and Company (Original work published 1971).

Steinberg, D. D., Nagata, H., \& Aline, D. P. (2001). Psycholinguistics Language Mind and World, London: Longman.

Sudaryanto. (1992). Metode Linguistik: ke Arah Memahami Metode Linguistik. Yogyakarta: Gajah Mada University Press. 